\title{
Glossary of Terms and Acronyms
}

Benshengren "This province people," the descendants of the original Chinese colonists of Taiwan

ETCC European Taiwanese Chamber of Commerce, regional level of representation of Taiwanese chambers of commerce

DPP Democratic Progressive Party, centre-leftist party in Taiwan

Guanxi A form of networking through mutual and reciprocal exchanges of favours

NCGU National Cheng Chi University

NTU National Taiwan University

KMT/Kuomintang "Republican Party" or "Chinese Nationalist Party," a political party founded in 1919, which took power in Taiwan following the 1949 migration from the mainland and remained in power until 2000; currently a centre-right party in Taiwan

Taipei Representative Offices Consular organizations representing Taiwan in countries that do not officially recognize Taiwan as an independent state

TAITRA Taiwanese Trade Association, an organization representing Taiwanese businesses in the UK

TMAT Taiwanese Merchants' Association of Toronto

Waishengren "Outside province people," Chinese people who migrated to Taiwan from the mainland in 1949, and their descendants

WTCC World Taiwanese Chamber of Commerce, international body of Taiwanese chambers of commerce 
This page intentionally left blank 